\title{
Tratamiento quirúrgico de las malposiciones dentales
}

\section{Surgical treatment of dental malpositions}

\author{
A. Jiménez Burkhardt', R. Fernández-Valencia Caballero², F. Pérez Fernández², \\ N. Toquero de la Torre ${ }^{2}, M$. Travesí Idañez ${ }^{2}$
}

Resumen: Presentamos los resultados obtenidos tras 17 años de experiencia en el tratamiento quirúrgico de las malposiciones dentales. Se incluyen los autotrasplantes de molares incluidos, autotrasplantes de caninos retenidos y reubicación de incisivos, caninos o premolares mal posicionados; 81 piezas dentales en total, de los cuales 60 dientes corresponden a autotrasplantes y 21 a reubicaciones, obteniendo un alto porcentaje de éxito.

Se explica en detalle las indicaciones, técnica quirúrgica y resultados, concluyendo en que a la vista de los mismos, la manipulación quirúrgica de dientes retenidos sanos tiene un alto porcentaje de éxito a largo plazo.

Palabras clave: Autotrasplante dental; Reubicación dental; Dientes retenidos.

\section{Introducción}

La reimplantación y el transplante de dientes han sido practicados durante siglos, pero generalmente fracasaban por complicaciones en la cicatrización.

Ya en 1771, John Hunter (precursor de las reimplantaciones y transplantes dentales) demostró que un diente humano heterotransplantado dentro de una cresta de gallo «se adhería en cualquier lado de la cresta por vasos, en forma similar a la unión de un diente con encías y alvéolos». ${ }^{1}$ En 1915, Widman describía la técnica de los implantes y transplantes dentales, posteriormente en 1948 y 1951, Apfel y Millar investigaban acerca de la etiología y patogenia de la reabsorción radicular. Las numerosas investigaciones realizadas en los últimos 30 años acerca de los procesos de cicatrización de heridas en la pulpa, el periodonto y la forma en que

\footnotetext{
1 Médico Estomatólogo, Cirujano Oral y Maxilofacial

2 Licenciada en Odontología

Granada, España
}

\section{Correspondencia:}

Clínica Alberto Jimenez Burkhardt

C/ Dr. Buenaventura Carreras n ${ }^{\circ} 11$

Apdo. 18004 Granada, España

E-mail: alberto@clínica-ajb.com

\begin{abstract}
We present the results obtained during our 17 years of experience in surgical treatment of dental malpositions. We include the autotransplantation of embedded molars, autotransplantation of retained canines and the repositioning of malpositioned incisors, canines and premolars; A total of 81 teeth, 60 autotransplanted and 21 repositioned, with a large degree of success.

Detailed explanation is given regarding the surgical indications, techniques and results. In view of this, a conclusion is reached regarding the high, long-term success rate of surgical manipulation of embedded, healthy teeth.
\end{abstract}

Key words: Dental autotransplantation; Dental repositioning; Embedded teeth.

\section{Introduction}

Re-implantation and transplantation of teeth has been practiced for centuries, but it has generally failed due to healing complications.

In 1771 John Hunter (forerunner of dental re-implantations and transplantations) demonstrated how a human tooth heterotransplanted in the crista galli would fix itself to either side of the crest by means of vessels, similar to the way in which a tooth is joined to gums and alveoli. ${ }^{1}$ In 1915 Widman described the technique of implants and dental transplantations and following this, in 1948 and 1951, Apfel and Millar investigated the etiology and pathogens of root re-absorption.

The large number of investigations that have been carried out over the last 30 years with regard to the healing processes of pulp wounds, the periodontium and their relationship with infection, as well as the advances which have been so important in diagnostic tools such as the high resolution optical microscope and radiological apparatus (RVG), have turned dental re-implantations and transplantations into generally reliable and predictable clinical procedures.

Shulman claimed that a transplanted tooth could last as long in the mouth as a normal tooth, if there was no occurrence of rhizolysis. Therefore, why are we currently disposining of so many healthy, extracted teeth? 
se relacionan con la infección, así como el avance tecnológico, tan importante en medios diagnósticos, como la microscopia óptica de alta resolución y en aparatología radiológica (RVG), tornaron predecibles la reimplantación y el transplante dentario, convirtiéndolos en procedimientos clínicos generalmente fiables.

Shulman, postula que un diente trasplantado puede durar en boca tanto como un diente normal, no habiendo fenómenos de rizólisis. Entonces: ¿Por qué desechar la cantidad de dientes que se extraen sanos actualmente?

Las publicaciones a este respecto son escasas siendo el profesor Andreasen, el maestro y promotor de la idea, y basados en sus conocimientos hemos desarrollado nuestro trabajo. En el presente artículo exponemos los resultados obtenidos tras trasplantar y reubicar numerosas piezas dentales.

\section{Material y método}

El objetivo del presente trabajo, es comunicar los conocimientos adquiridos durante los últimos 17 años, plantear las indicaciones, comentar los diferentes aspectos de la técnica quirúrgica, presentar nuestros resultados, para poder afirmar que estas actuaciones son totalmente predecibles y que bajo el punto de vista científico actualmente son de elección a otros tratamientos tradicionales, y su desconocimiento es la única razón para no aplicarlos. ${ }^{2}$

Durante este período, hemos realizado más de cien movimientos dentales con cirugía, por lo que hemos llamado genéricamente a esta técnica: Ortodoncia quirúrgica.

Es necesario definir antes de seguir, la nomenclatura exacta de cada tipo de intervención, con el fin de poder clasificarlas y evitar confusiones. Por ello, pasamos a definir los siguientes conceptos:

- Reimplante dental. Colocación de un diente en su alvéolo, tras haber sufrido su avulsión por un traumatismo.

- Reubicación dental. Movimiento de un diente en un acto quirúrgico, con el objeto de colocar en la situación idónea en la arcada, un diente o más, que previamente se encontraban malposicionados. ${ }^{3}$

- Autotrasplante dental. Extracción de un diente permanente incluido o impactado, realización de un neoalvéolo y recolocación del diente en su nueva posición.

Nuestro trabajo lo vamos a centrar preferentemente en los apartados de las movilizaciones dentarias programadas en la clínica aunque daremos unas directrices generales de la conducta a seguir ante un diente avulsionado, ya que los traumatismos suelen acudir a centros hospitalarios.

En los cinco últimos años, la bibliografía relacionada con la perdida dental, ha estado más en concordancia con el boom de la rama ortodoncica y protésica íntimamente unidas al aspecto estético. Nosotros nos hemos planteado la posibilidad de utilizar dientes retenidos para ocupar estos espacios vacíos, manipulándolos adecuadamente y demostramos en este trabajo que esta técnica es de elección siempre que seleccionemos adecuadamente a los pacientes.

En los últimos 17 años hemos realizado en nuestra clínica más de cien intervenciones de las que tenemos documentados unos
There are few publications in this respect and it was based on the knowledge of professor Andreasen, master and promoter of this concept, that we have we have carried out our work. In this report we set out the results obtained following the transplantation and repositioning of numerous teeth.

\section{Material and method}

The object of this report is to share the knowledge we have acquired over the last 17 years. We suggest the indications for, and comment on the different surgical techniques, we discuss their different aspects and present our results. We do this in order to stress that these proceedings are completely predictable, and that from a scientific point of view, they should be chosen over other traditional treatments, and that it is only because of unfamiliarity that they are not. ${ }^{2}$

During this period, we have surgically moved more than a hundred teeth, and for this reason we have generically called this technique: surgical orthdontia.

Before proceeding, defining the terminology exactly of each type of intervention is necessary so as to be able to classify them and avoid confusion. We will therefore proceed to define the following concepts.

- Dental re-implantion. Placement of a tooth in its alveolus, following avulsion through traumatic injury.

- Dental repositioning. Surgical movement of a badly positioned tooth (or more), in order to place it in a suitable location in the arch. ${ }^{3}$

- Dental autotransplatation. Extraction of a permanently embedded or impacted tooth, creating a «new socket», and placement of the tooth in its new position.

We have preferred to concentrate our study on programmed dental movements in our clinic, although we will give some general guidance on what course to follow with an avulsed tooth, although injured patients tend to go to hospital centres.

In the last five years, bibliography related to tooth loss has been more in accordance with the boom in the orthodontic and prosthetic section, closely linked to aesthetic appearances. We considered the possibility of using embedded teeth to occupy these empty spaces, of handling them adequately and of showing that, in this field, this is the technique of choice providing patients have been adequately selected.

In the last 17 years we have carried out over one hundred interventions in our clinic, 80 of which have been documented and which have been very successful. Follow-up protocol was based on a 2-year period following surgery in all cases.

\section{Surgical Indications and patient selection ${ }^{4}$}

\section{Autotransplantation of canines}

Age. Ideal patients are those aged between 15 and 30. In younger patients, with permanent dentition and open apexes, autotransplantation is recommended, as revascu- 
ochenta con resultados muy satisfactorios. Los protocolos de seguimiento se han realizado en un plazo de 2 años posterior a la cirugía en cada uno de los casos.

\section{Indicaciones y selección de casos}

\section{De los autotrasplantes de caninos 4}

Edad. Son pacientes de elección los de edades comprendidas entre 15 y 30 años. En pacientes demasiado jóvenes, en dentición permanente y con ápice abierto esta indicada el autotrasplante, ya que favorece la revascularización. En pacientes mayores hemos tenido todos nuestros fracasos y consideramos que debe ser debido a un problema de revascularización periodontal y apical.

Situación. Caninos muy altos o con un grado de inclinación tal que ensombrezcan el pronóstico del tratamiento conservador.

Oclusión. Espacio interdentario suficiente para recolocar el canino y relación favorable con los antagonistas con el objeto de que no se creen interferencias oclusales.

Ortodoncia. Pacientes candidatos a ella que por motivos estéticos, de tiempo o económicos rechazan el tratamiento conservador.

De los autotrasplantes de molares-premolares 5,6

- La edad no es tan determinante como en los caninos, pues aunque hemos realizado pocos casos en personas en torno a los 40 años, no hemos tenido ningún fracaso. Técnicamente es la operación más fácil de las que realizamos.

- Ausencia o pérdida de un primer o segundo molar inferior, existiendo un tercer molar incluido o retenido sano, en buena posición y con raíces cónicas. La extracción de este molar debe ser atraumática, preservando el periodonto y eliminando los restos del saco pericoronario.

La preparación del neoalvéolo la haremos eliminando el hueso alveolar con una fresa de acero o tungsteno, redonda y con abundante irrigación.

- Espacio interdentario suficiente para colocar el molar pudiendo hacer un pequeño striping, si fuera necesario. Liberar la oclusión con su antagonista.

- Suficiente altura ósea para no lesionar el nervio dentario.

\section{De los reimplantes dentales}

Se trata de urgencias que acuden a la consulta de un odontoestomatólogo o a un hospital. El caso típico es el de jóvenes que han sufrido un traumatismo dentoalveolar y han sufrido la pérdida de uno o varios dientes. No tratamos este apartado en nuestro trabajo aunque escuetamente diremos que un reimplante dental se puede realizar siempre que el diente y el alveolo estén limpios y no haya transcurrido más de una hora desde el accidente y se informe correctamente a los padres de las posibilidades del fracaso. Depositaremos el diente avulsionado en suero salino estéril, limpiaremos el alvéolo con una cucharilla eliminando restos de coágulos, comprobaremos la integridad del alvéolo mediante una RX intraoral y colocaremos el diente en su posición. larization is favoured. We have all had our failures with older patients and we feel that this is due to problems with periodontal and apical revascularization.

Location. High canines with a degree of inclination which, with conservative treatment, would have a gloomy prognosis.

Occlusion. sufficient space between teeth to allow repositioning of the canine and a favourable location with antagonists so that avoid occlusal interference is avoided.

Orthodontia. candidates are those patients who for aesthetic reasons, or for time of economic reasons, reject conservative treatment.

Molar-premolar autotransplantation ${ }^{5,6}$

- Age is not such a determining factor as with canines, as although we have carried out very few cases in people who are about 40 years old, we have had no failures. Technically it is the easiest operation that we do.

- Absence or loss of the first or second inferior molar, when there is a third healthy molar that is included or embedded, in a favourable position and with conical roots. Extraction of this molar should be atraumatic, the periodontium should be preserved and the remains of the pericoronary sack eliminated. Preparation of the new socket should be done by eliminating the alveolar bone with a rounded, steel drill or tungsten with extensive irrigation.

- Sufficient space between teeth to allow for the placement of the molar. A little stripping can be carried out if necessary. Correct occlusion with antagonist.

- Sufficient bone height so as not to damage the dental nerve.

\section{Dental Re-implantation}

These are emergency cases that go to a dental practice or to a hospital. Youngsters that have experienced dentoalveolar trauma and that have lost one or various teeth are typical cases. We do not cover this area in this report although we will mention briefly that dental re-implantation can be carried out if the tooth and the alveolus are clean, and if parents have been correctly advised about the possibility of failure. The avulsed tooth should be deposited in sterile saline serum, and the alveolus should be cleaned with a spoon-shaped instrument in order to eliminate coagulation remains. The alveolus should be checked to confirm that it is complete undamaged with an intra-oral $x$-ray, and the tooth is then placed in its position. Ideal fixation would be with a little composite on neighbouring teeth and protection with Peripac.

\section{Repositioning of incisors ${ }^{3}$}

- Lateral superior incisors, palatally positioned or with vestibular inclination, providing all other teeth have correct occlusion.

- Sufficient space between the central incisor and the canine 
La fijación ideal sería con un poco de composite a los dientes vecinos y protección con Peripac.

De las reubicaciones de incisivos ${ }^{3}$

- Incisivos laterales superiores palatinizados o vestibulizados, siempre que el resto de los dientes estén en correcta oclusión.

- Espacio entre el incisivo central y el canino suficiente, aunque haya que realizar un pequeño striping para recolocar el diente.

- Espacio óseo interradicular suficiente, visible en la ortopantomografía, con objeto de no dañar las raíces de los dientes contiguos.

- La edad no es determinante pues el movimiento dental lo hacemos en bloque, previa osteotomía.

- En algunas ocasiones hemos tenido la oportunidad de movilizar dos dientes a la vez, con buenos resultados

\section{Técnica quirúrgica}

Es evidente que, como cualquier operación quirúrgica, no se exime al paciente de molestias post-operatorias, por todo lo cual hay que seguir con disciplina una serie de cuidados tanto en el precomo en el post-operatorio. Será necesaria una cobertura antibiótica y antiinflamatoria, ${ }^{7}$ así como una dieta blanda-liquida y la mentalización por parte del paciente de que durante ese periodo de tiempo de adaptación no debe realizar deporte ni trabajos de esfuerzo, no fumar, ni beber alcohol y por supuesto deberá evitar la masticación hasta que se dé por concluido el proceso. Cualquier alteración de estas pautas puede llevar a unos resultados poco o nada satisfactorios.

En general, la manipulación quirúrgica de los dientes, tiene unas connotaciones básicas que son válidas para cualquier cirugía bucal y otras características específicas que vamos a comentar.

Este tipo de actuaciones, bajo el prisma de la cirugía máxilofacial, las podemos incluir dentro del marco de la cirugía menor ya que las podemos realizar con anestesia local, en régimen ambulatorio, su duración es inferior a una hora y no precisan de pruebas complementarias ni otro tipo de exploraciones para su realización.

Ello no quiere decir que la persona que realiza esta cirugía no tenga una preparación adecuada, tanto es así que incluso dentro del ambiente de cirujanos máxilofaciales, muchos de ellos deberían conocer los aspectos ténicos específicos, para su correcta ejecución.

Realizamos estas intervenciones en un quirófano adecuado de cirugía oral, con anestesia infiltrativa y troncular, según el caso y si fuera posible con la ayuda de una sedación pre o intraoperatoria. Preparamos un campo estéril similar al que hacemos en implantología precisando como aparatología rotatoria, una pieza de mano con fresa de tungsteno y una turbina con fresa de tungsteno de fisura para realizar la corticotomía.

Siempre irrigaremos con suero salino estéril procurando no calentar el hueso.

Los colgajos mucoperiósticos serán amplios, alejando las incisiones de las osteotomías, y procurando que el despegamiento mucoperióstico sea limpio, sin desgarros. Evitaremos el sufrimien- even though a small amount of stripping may have to be carried out in order to reposition the tooth.

- Sufficient inter-radicular space on the bone, visible in the orthopantomography, so as not to damage the roots of adjacent teeth.

- Age is not a determining factor as the dental movement is done as a segment, following an osteotomy.

- On occasions we have been able to move two teeth at once with good results.

\section{Surgical technique}

As with all surgical operations the patient will obviously not be free of postoperative discomfort, and a series of preand postoperative instructions have to be strictly followed. Antibiotic and anti-inflammatory protection ${ }^{7}$ will be needed, as well as a liquid-soft diet, and the patient has to realize that during the adaptation period he cannot play sport, or indulge in strenuous activity, nor smoke nor drink alcohol, and he will have to avoid chewing until the process has been concluded. Any change to these guidelines could lead to results giving little satisfaction or none at all.

Surgical manipulation of teeth has, in general, basic connotations which are valid for any oral surgery, and other more specific characteristics that we will discuss.

These types of procedures, under the prism of maxillofacial surgery, can be included in the framework of minor surgery, as they can be carried out with local anaesthetic on a day patient basis, their duration is under an hour, and no additional tests nor any other type of examination are required.

This does not mean to say that the person carrying out this surgery does not have proper training. For such is the case, that even in the ambit of maxillofacial surgeons, many of them should know the specific, technical aspects of this surgery in order to execute it correctly.

These interventions should be carried out in a suitable operating room for oral surgery, with truncal and infiltrative anaesthesia, according to each case, and if possible with the help of pre-or intraoperative sedation. A sterile area is prepared, similar to that used in implantology, with rotating apparatus, a handpiece with tungsten drill, and a turbine drill for fissures in order to perform a corticotomy.

Irrigation carried out with sterile saline serum taking care not to heat the bone.

The mucoperiosteal flaps will be ample, and these incisions will be away from the osteotomies. An effort should be made to ensure that the separation of the mucoperiosteum should be cleanly done with no tears. In order to avoid harming them the separators of the assistant should be used.

Not touching the radicular area of the teeth with the drills or with the fingers so as not to harm the periodontal ligament is of fundamental importance. And, if we have to take the tooth out of the mouth, we should do this for as short a 
to de ellos por los separadores del ayudante.

Es fundamental no tocar la superficie radicular de los dientes con las fresas ni con los dedos para no lastimar el ligamento periodontal $y$, si tenemos que sacar el diente fuera de la boca, será durante el menor tiempo posible y en ese intervalo, lo colocaremos en suero estéril.

\section{Autotrasplante}

En el caso de los caninos incluidos, normalmente habrá que realizar un colgajo palatino para acceder al diente (Fig.1). ${ }^{8}$ Con la pieza de mano eliminaremos el hueso necesario para poder extraerlo. Es aconsejable disponer de un filtro de hueso para poder reutilizarlo al final en el relleno de defectos. Con suma precaución, expondremos la corona del canino y buscaremos unos apoyos para poder movilizar el diente con la ayuda de botadores rectos. Los movimientos serán muy controlados procurando no fracturar la raíz. Cuando hayamos conseguido la extracción lo depositamos en suero y comenzamos a realizar el neoalvéolo, con la ayuda de la pieza de mano recta, fresa redonda y abundante irrigación. Llegado el momento comprobamos el diente en su nueva situación procurando que la raíz no toque ni presio-

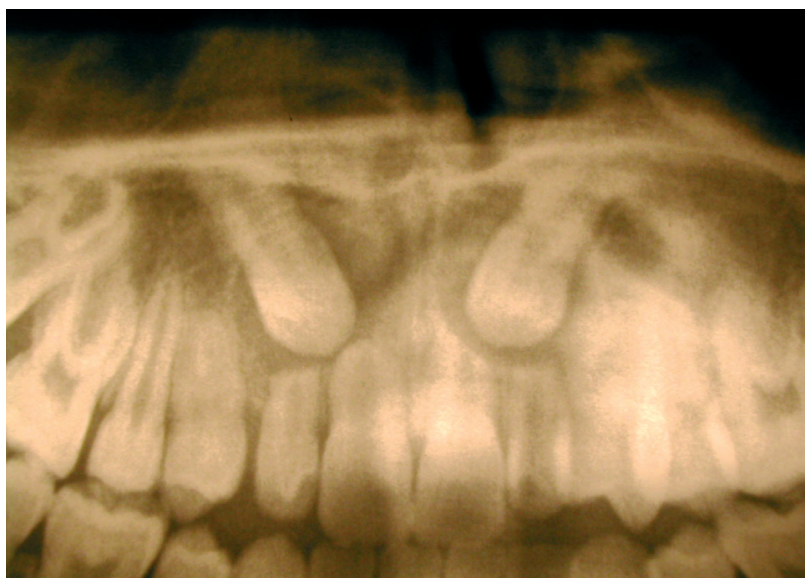

Figura 1. Estudio radiográfico anterior a la cirugía (visualización de caninos incluidos y rizolisis de incisivos laterales).

Figure 1. Radiographic study previous to surgery (impacted canines and rhizolysis of lateral incisors visible).

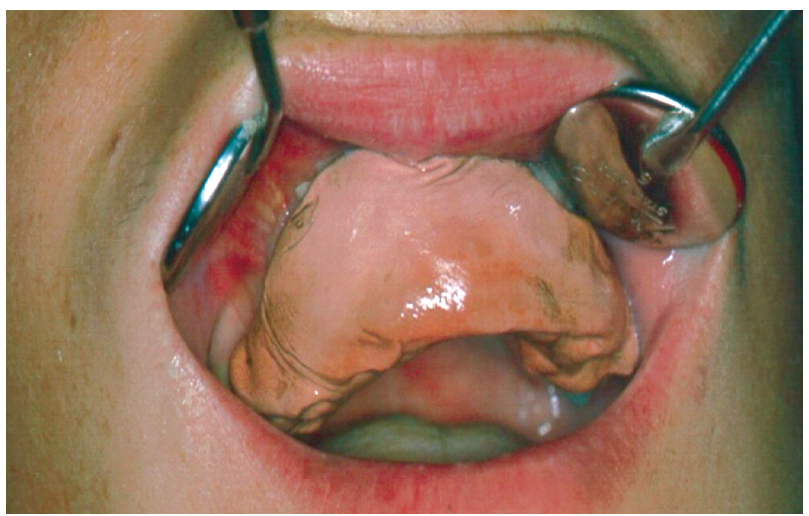

Figura 2. Ferulización elástica con Peripac.

Figure 2. Elastic splinting with Peripac. period as possible, and during this interval it should be placed in sterile serum.

\section{Autotransplantations}

In the case of embedded canines, normally a palatine flap will have to be carried out in order to reach the tooth (Fig. 1)8. The bone necessary to permit extraction will be removed with the use of a hand-held instrument. It is advisable to have a bone filter so as to be able to reuse it at the end for filling in defects. With extreme care we will expose the crown of the canine, and we will look for support so that the tooth can be moved with the aid of straight stabilizers. So as not to fracture the root, movements should be very controlled. Once the extraction has been achieved, the tooth is deposited in serum, and we will start making the "neo-alveolus», with the aid of a rounded, straight drill and with much irrigation. The tooth is then tried in its new position making sure ne el hueso circundante sino que quede un espacio entre ambos, que será ocupado por el coágulo que posteriormentese reorganizará y formará un hueso alveolar maduro y una regeneración del ligamento periodontal.

La corona la fijaremos por fricción entre el lateral y el premolar, tallando las caras interproximales hasta que se mantenga en una posición adecuada en oclusión liberado de cargas. A continuación suturamos los colgajos con puntos de 5/0 tipo colchonero, lavamos con suero salino y fijamos el diente. Es de una trascendencia vital comprobar que no existen contactos del diente trasplantado con sus antagonistas en todos los movimientos mandibulares. La ferulización,9, 10 la podemos hacer con Peripac (Fig. 2), durante diez días y posteriormente con un composite fluido durante otra semana. ${ }^{11-13 .}$ Prescribimos antibióticos, antiinflamatorios y protección gástrica y dieta líquida y enjuagues con un colutorio de Clorhexidina, los 15 primeros días. Es de gran importancia para la salud gingival comenzar a masajear la encía con un cepillo quirúrgico desde el momento que retiramos el Peripac. (Figs. 3 y 4). Durante los 15 días siguientes recomendamos dieta muy blanda, masaje gingival y le facilitaremos una férula de descarga oclusal. 14,15 that the root neither touches nor is pressed against the bone surrounding it, but rather that a space is left between them. This will be occupied by the clot which will subsequently be formed and which will turn into a mature alveolar bone and regenerate the periodontal ligament.

The crown will be secured by means of friction between the lateral incisor and the premolar, and the interproximal surfaces will be shaped until it is in an adequate position with correct occlusion. Following this we will suture the flaps with 5/0 type blanket stitches, rinse with saline serum and secure the tooth. It is of vital importance that there is no contact between the tooth that has been transplanted with its antagonist in all mandibular movements. Splinting 9,10 for ten days can be done with Peripac (Fig. 2) and after this a fluid composite can be used for another week. ${ }^{11-13}$ Antibiotics, anti-inflammatory and gastric protection are prescribed. A liquid diet and mouthwashes with Chlorhexidine are recommended for the first two weeks. It is important for the health of the gums to start massaging them with a surgical brush as soon as the Peripac is removed (Figs. 3 and 4). Dur- 
El autotrasplante de molares sigue las mismas pautas que el de los caninos, siendo menor el tiempo de ferulización por su mejor estabilidad primaria (Figs. 5 a 8$)$.

\section{Reubicaciones}

Lo más frecuente que nos podemos encontrar es el caso de un incisivo lateral superior desplazado hacia palatino, por falta de espacio (Figs. 9 y 10). ${ }^{3}$ Una vez que hemos levantado el colgajo, dibujamos con rotulador fino, las líneas de osteotomía que irán entre los dientes con el objetivo primordial de no lesionar lar raíces de los dientes vecinos. Con turbina y una fresa de Tungsteno, larga y fina, marcamos la osteotomía (Fig. 11) y después profundizamos en el hueso vestibular hasta llegar al hueso palatino. Se trazan dos líneas de osteotomía perpendiculares, paralelas a la raíz del diente mesial y distal al mismo y una tercera horizontal supraapical. Terminada la osteotomía, repasamos con un escoplo fino y estrecho comenzando a movilizar el bloque óseo. ${ }^{15}$ Tallamos con fresa de diamante las caras interproximales de los dientes para que al movilizar el bloque el diente movilizado quede perfectamente colocado entre sus vecinos. Esta movilización que iniciamos con escoplo, la terminamos con nuestros dedos. Una vez en oclusión, sin carga, suturamos e inmovilizamos, pero en esta ocasión durante un mes, para asegurarnos una formación de callo óseo en el lugar de las osteotomías. Las pautas de higiene y tratamiento son comunes a todos los procedimientos (Fig. 12).

\section{Resultados}

De la tabla 1 se deduce que de los tres grupos de trabajo, en los autotrasplantes de caninos y premolares, se ha obtenido una tasa de éxito del 86,4\%, de los 44 casos revisados en los últimos dos años; en el caso de los autotrasplantes de molares, el éxito ha sido del $100 \%$, de los 16 casos revisados en los últimos dos años. Las reubicaciones han resultado exitosas en el $100 \%$ de los 21 casos controlados en el mismo período.

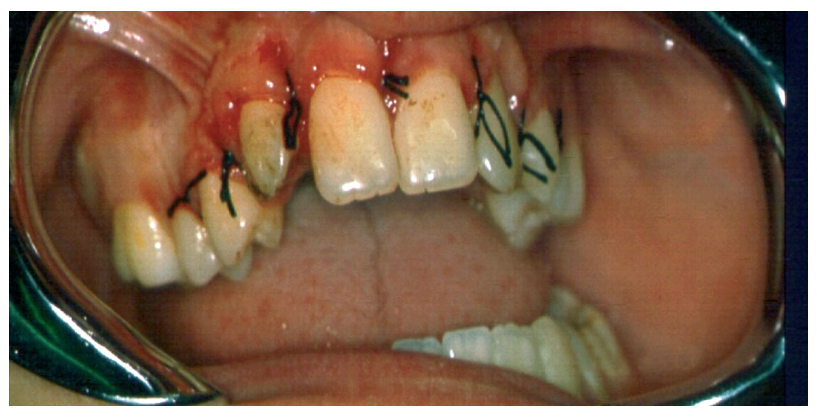

Figura 3. Post-operatorio inmediato, $10^{\circ}$ día, al retirar el Peripac. Figure 3. Immediately after operation, day ten, on removing Peripac.

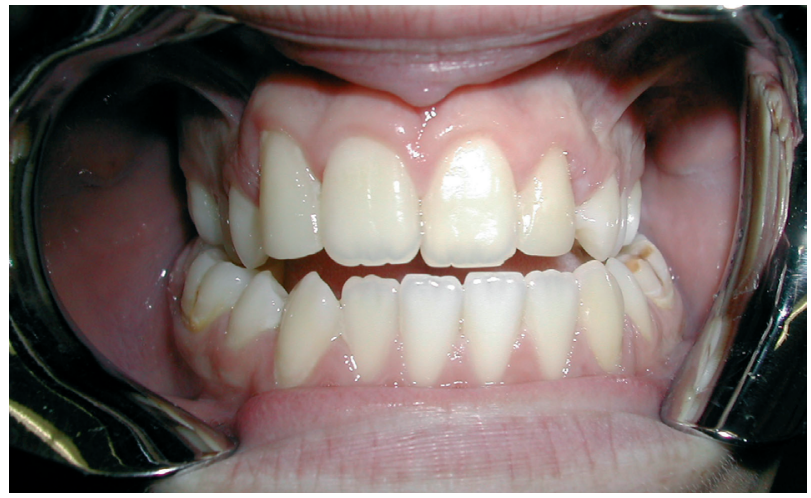

Figura 4. Post-operatorio a los 3 meses. Caninos tallados con forma de incisivos laterales.

Figure 4. Post-operative at 3 months. Canines grafted into the form of lateral incisors.

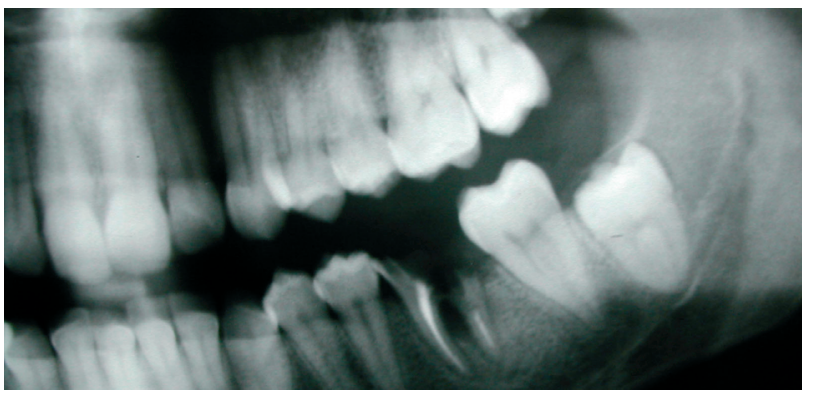

Figura 5. 36 destruido y 38 incluido sano y con raíces cónicas. Figure 5. 36 destroyed and 38 embedded healthy molars with conic roots.

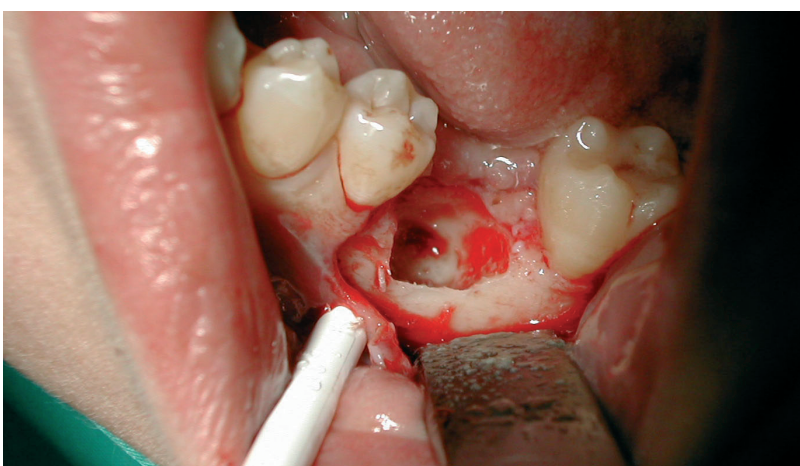

Figura 6. Restos radiculares extraídos y preparación quirúrgica de un neo-alveolo.

Figure 6. Remains of extracted root and surgical preparation of new socket. ing the next two weeks a very soft diet is recommended together with gingival massages and a tooth guard is provided. 14,15

The guidelines for the autotransplantation of molars are similar to those of canines, but splinting time is inferior as there is better primary stability (Figs. 5,6,7 and 8).

\section{Repositioning}

What we are most frequently likely to find is a superior lateral incisor displaced towards the palatine because of lack of space (Figs. 9 and 10). ${ }^{3}$ Once the flap has been lifted, with a fine tipped felt pen we draw the lines of the osteotomy which will go between the teeth with the fundamental objective of not damaging the roots of the neighbouring teeth. With a turbine and a long, fine, Tungsten drill we mark out the osteotomy (Fig. 11). We then go deeper into the vestibular bone until the palatine bone is reached. Two perpendicular lines of the osteotomy are traced, parallel to the root of the mesial tooth and distal tooth and a third horizontal supra-apical line. Following the osteotomy, with a fine, narrow chisel we start moving the segment of bone. ${ }^{15}$ With a diamond drill we carve the interproximal surfaces of the teeth so that when the segment is moved the transplanted tooth is perfectly positioned between the neighbouring teeth. This movement, which we started with the chisel, we finish with our fingers. Once in proper occlusion, we suture 


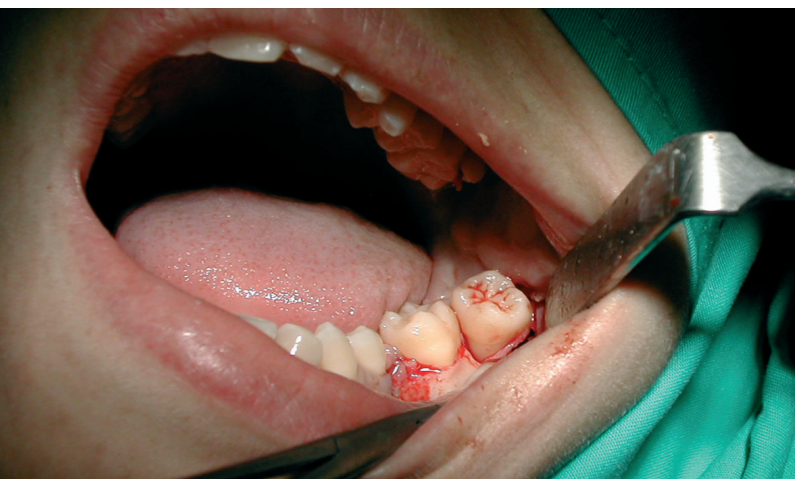

Figura 7. Extracción quirúrgica del cordal incluido.

Figure 7. Surgical extraction of embedded wisdom tooth.

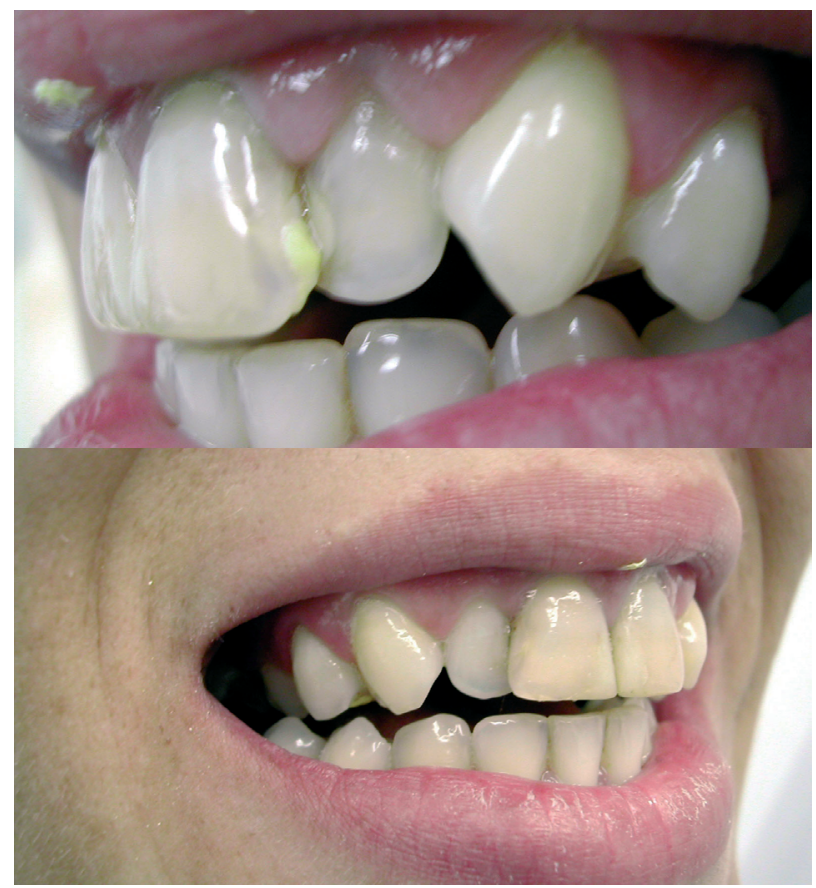

Figuras 9 y 10. Fotografías vistas laterales previas a la cirugía. Figures 9 and 10. Photographs with side view previous to surgery.

\section{Discusión}

El tratamiento quirúrgico de las malposiciones dentales, es una práctica muy limitada en nuestro país tanto a nivel de clínicas privadas, como hospitalario. Las razones de porqué no se llevan a cabo estas intervenciones, creemos que son las siguientes:

- Falta de formación en las facultades de Odontología por no encontrarse suficientemente tratados estos temas en los programas de Patología Quirúrgica, por lo que los profesionales no tienen acceso a su conocimiento y por lo tanto a su desarrollo posterior en la clínica.

- A nivel hospitalario, los futuros cirujanos máxilofaciales, en su período de formación como M.I.R., únicamente tienen contacto con la traumatología dentoalveolar, lo que es insuficiente para llevar a cabo este tipo de intervenciones con éxito.

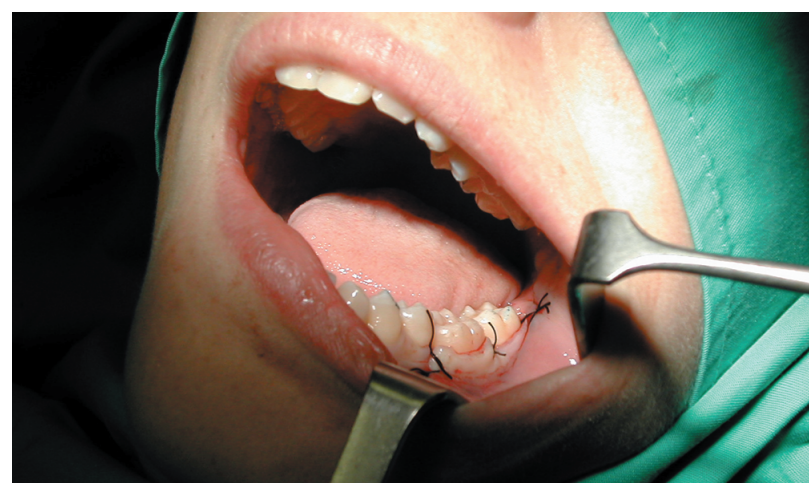

Figura 8. Colocación del cordal en el neo-alveolo y sutura. Figure 8. Placement of wisdom tooth in new socket and suture.

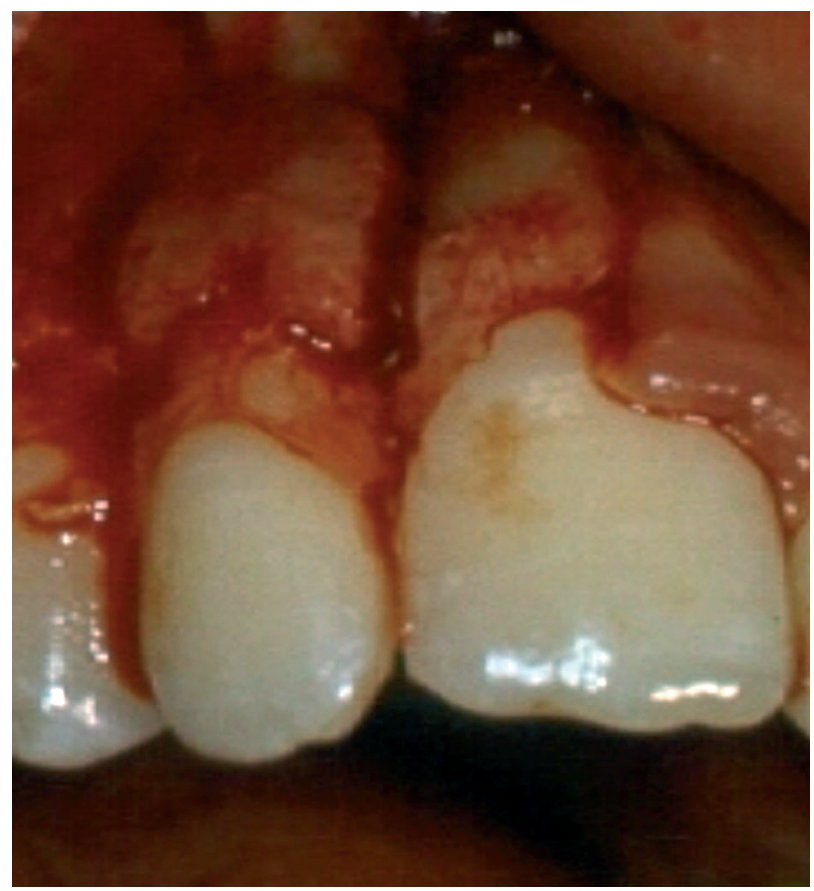

Figura 11. Corticotomía.

Figure 11. Corticotomy.

and immobilise the area, but on this occasion for a month, in order to ensure that a bone callus is formed in the area of the osteotomy. The guidelines for hygiene and treatment are the same for all proceedings (Fig. 12).

\section{Results}

It can be deduced from the three work areas of Table 1 that in the autotransplantation of canines and premolars, a success rate of $86,4 \%$ was achieved in 44 of the cases reviewed in the last two years; in the case of autotransplantation of molars, there was a $100 \%$ success rate in the 16 cases reviewed in the last two years. Repositioning was 100\% successful in the 21 cases controlled over the same period. 
- Faltan cursos de formación postgraduada como consecuencia de todo lo anterior, lo que implica que existe un vacío en este campo de la terapéutica quirúrgica. En la actualidad la falta de espacio se soluciona mediante la ortodoncia y prótesis, en vez de con las soluciones antes expuestas. ${ }^{16,17}$

- El amplio desarrollo que han experimentado en los últimos años los implantes dentales, completa el círculo y prácticamente son inexistentes las publicaciones relacionadas con estos temas. ${ }^{6,18}$

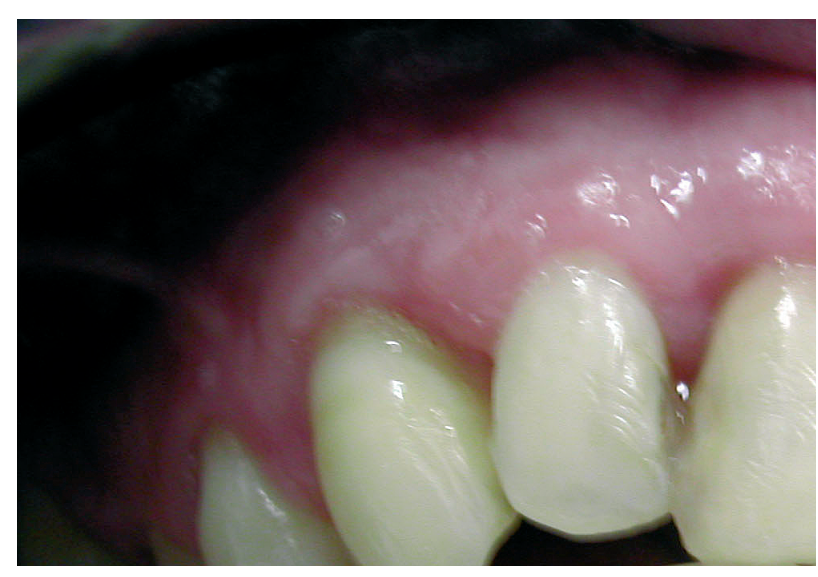

Figura 12. Semanas después de la cirugía. Figure 12. Weeks after surgery.

\section{Discussion}

Surgical treatment for dental malpositions is a very limited practice in our country in private clinics as well as in hospitals. We believe the reasons behind this are the following:

- Lack of training in the Faculties of Odontology as these areas are not covered sufficiently in the programmes of Surgical Pathology. Professionals therefore do not have access to training in the technique and consequently they are not able to develop it later in the clinic.

- On a hospital level, future maxillofacial surgeons, during their formation as resident doctors, only have contact with diente trasplantado favorece la ulterior rizolisis o anquilosis. ${ }^{9,10}$

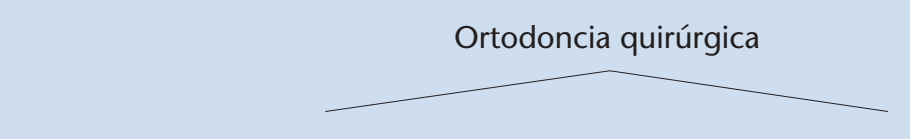

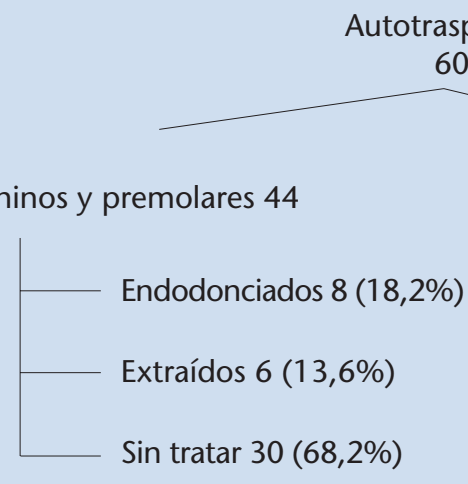

60

Caninos y premolares 44
Molares 16

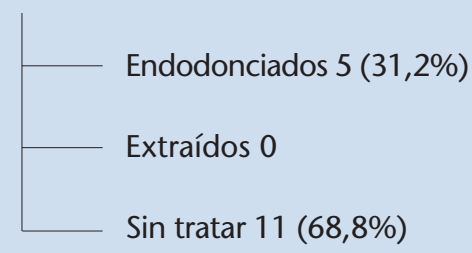

Reubicaciones

Caninos e incisivos

21

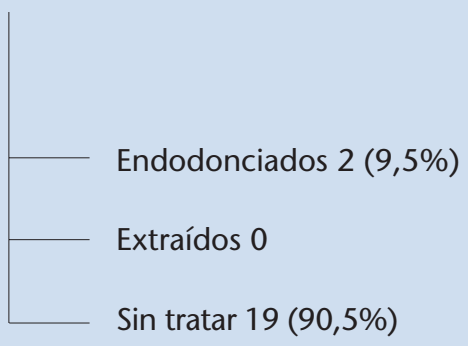

Tabla 1. Casuística de los dientes que hemos sometido a tratamiento.

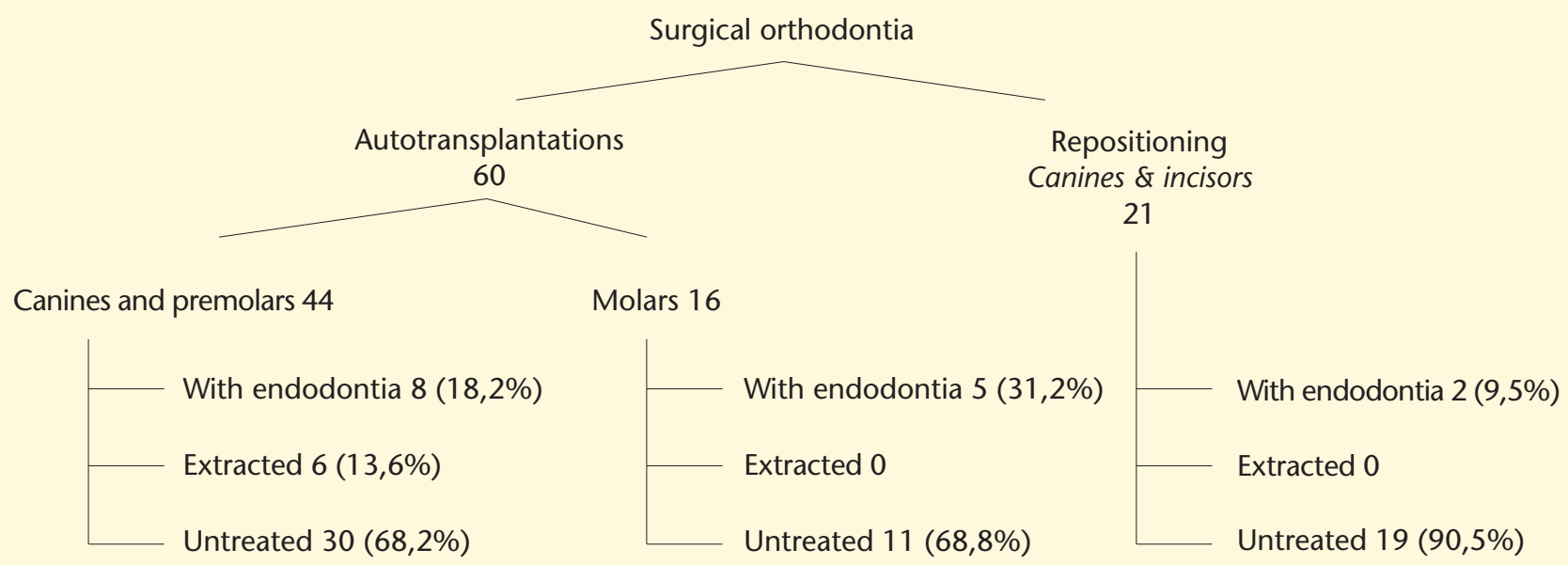

Table 1. Case reports of treated teeth. 
En las reubicaciones dentales, en las que hacemos una osteotomía del bloque alveolar y no fijamos con miniplacas, sí ferulizamos el diente movido a los dientes vecinos mediante un alambre y composite.

No desvitalizamos los dientes en el acto quirúrgico, sino que lo hacemos solo en caso de que den patología.

A pesar de todo ello, pensamos que se trata de una práctica predecible y con buen pronóstico, como demostramos en el presente trabajo, avalados por otra serie de publicaciones en revistas internacionales. $2,5,6,16-19$

\section{Conclusiones}

1. No hay razones para reemplazar un primer molar inferior mediante prótesis fija dento o implantosoportada, habiendo un tercer molar incluido, en una persona joven, salvo el desconocimiento de que se puede trasplantar dicho molar.1,5

2. No hay razones para extraer un canino incluido sano y sustituirlo por una prótesis sobre un implante osteointegrado. Ese diente, es el mejor implante que le podemos colocar a nuestro paciente, además de ser mas económico para el paciente.

3. La reubicación de un incisivo lateral superior puede realizarse en un solo acto quirúrgico de $\mathbf{4 0}$ min de duración en régimen ambulatorio, lo que evita un tratamiento ortodóncico durante uno o varios años. 3,19

4. En base a los resultados obtenidos por nuestro grupo de trabajo, estamos en condiciones de afirmar que las razones que se argumentaban en contra de estos tratamientos, carecen de base científica y los responsables de elaborar los programas de formación deberían informarse e incluirlos en asignaturas, máster y ciclos formativos Con un entrenamiento quirúrgico adecuado, una técnica no traumática y una selección cuidadosa de los casos, los movimientos dentales en un acto quirúrgico en régimen ambulatorio, con anestesia local, constituyen una posibilidad de tratamiento con un pronóstico favorable. Se puede afirmar que la vieja idea de que el trasplante dental equivale a la rizolisis y pérdida del diente tratado, pertenece al pasado de la historia de la medicina, en nuestro país.

\section{Bibliografía}

1. Andreasen JO. Reimplantación y Trasplante en Odontología. Buenos Aires, Argentina: Ed. Médica Panamericana

2. Peñarrocha MA, Peñarrocha M, García Mira B. Transplantes dentales, una alternativa en el tratamiento quirúrgico-ortodóncico de los dientes incluidos. Arch Odontoestomatol 2003;19:245-51.

3. Pérez Fernández F, Jiménez Burkhardt A. Reubicaciones dentales. Rev Europ Odont 1995;7:273-6.

4. William M. Northway, Sydney Konigsberg. Autogenic tooth transplantation. Am J Orthod 1980;77:146-62.

5. Josefsson E, Brattstüm V, Tessjö Ulf, Valerius Olsson H. Treatment of lower second premolar agenesis by autotransplantation: four year evaluation of eighty patients. Acta Odontol Scan 1999;57:111-5. dentoalveolar traumatology, which is insufficient for carrying out these types of interventions successfully.

- There is a lack of post-graduate training as a result of the former, which implies that there is a void in this field of surgical therapy. The lack of space is currently solved through orthodontia and prostheses, instead of the solutions previously mentioned. ${ }^{16,17}$

- The considerable development in dental implants over the last years completes the circle, and publications on this issue are practically nonexistent. 6,18

- The splints we use are semi-rigid (Sutura and Peripac), coinciding with other professionals who corroborate that complete immobilization of the transplanted tooth encourages later rhizolysis or anquilosis. 9,10

When an osteotomy is performed of the alveolar segment during dental repositioning in which mini-plates are not used, we should secure the tooth we have moved to neighbouring teeth using a wire and composite.

Teeth should be surgically devitalised only in the event of there being a pathological necessity for doing so.

In spite of all this, we feel that surgical treatment of dental malpositions is a practice with a predictable and good prognosis, as demonstrated in this report, and that it is supported by other publications in international magazines. $25,6,16-19$

\section{Conclusions}

1. There is no reason for replacing a lower primary molar of a young person with a fixed prosthesis supported either by the tooth or by an implant, if there is an embedded third molar, unless there is a lack of knowledge regarding the transplantation the molar in question. 1,5

2. There is no reason for extracting an embedded healthy canine and substituting it with a prosthesis supported by an osteointegrated implant. This tooth is the best implant that we can fix in our patient, in addition to it being more economical for the patient.

3. The repositioning of a superior lateral incisor can be done in just one surgical act with a duration of 40 minutes on an outpatient basis, which avoids orthodontic treatment for a year or more. ${ }^{3,19}$

4. Based on the results our work group has obtained, we are able to confirm that the reasons given against these treatments, lack a scientific base, and those responsible for putting together training programmes should inform themselves and include them in the subjects of study, post-graduate courses and training courses. With correct surgical training, an atraumatic technique and careful case selection, surgical movement of teeth on an outpatient basis, with local anaesthesia, constitutes an option for treating patients with a favourable prognosis. It can be said that the old idea that dental transplantation is equivalent to rhizolysis and loss of the treated tooth belongs, in our country, to medical history. 
6. Czochrowska EM, Stenvik A, Bjorn Album and Bjorn U. Zachrisson. Autotransplantation of premolars to replace maxillary incisors: A comparison with natural incisors. Am J Orthod Dentofacial Orthop 2000;118: 592-600.

7. Patrikiou AK, Katsavrias EG. Reposicionamiento de caninos maxilares anquilosados mediante osteotomía segmentaria. J Clin Orthod 1995;29:625-8.

8. Medina Vega LD, Portal Fernández W, Ruiz Hernández A, Martín Pino J, Peydro Herrero M. Transplante autólogo de dientes retenidos: estudio de 10 años. Rev Esp Cirug Oral y Maxilofac 2003;25:85-9.

9. Bauss O, Schilke R, Fenske C, Engelke W, Kiliaridis S. Autotransplantation in mature third molars: influence of different splinting methods and fixation periods. Dent Traumatol 2002;18:322-8.

10. Gerard E, Membre H, Gaudy JF, Mahler P, y cols. Functional fixation of autotransplanted tooth germs by using bioresorbable membranes. Oral Surg Oral Med Oral Pathol Oral Radiol Endod 2002;94:667-72.

11. Magheri P, Grandini R, Cambi S. Autogenous Dental Transplants: Description of a clinical case. Int J Periodontics Restorative Dent 2001;21:36771.
12. Hans Ulrik Paulsen. Autotransplantation of teeth in orthodontic treatment. Am J Dento Orthop 2001;119:336-7.

13. Khongkhunthian $P$, Chantaramungkon $M$, Waranywwat $S$. The treatment of an avulsed maxillary central incisor by transplantation of an embedded mandibular premolar. Dent Traumatol 2002;18:335-8.

14. Bjerklin K, Bennet J. The long-term survival of lower second primary molars in subjects with agenesis of the premolars. European Journal of Orthod 2002;22:245-55.

15. Tsukiboshi M. Autotransplantation of teeth: requirements for predictable success. Dt Traumatol 2002;18:157-80.

16. Slagsvold O, Bjercke B. Applicability of autotransplantation in cases of missing upper anterior teeth. Am J Orthod 1978;74:410-21.

17. Schatz JP, Joho JP. Indications of autotransplantation of teeth in orthodontic problem cases. Am J Orthod Dentofac Orthop 1994;106:351-7.

18. Sagne $S$, Lennartsson $B$, Thilander B. Transalveolar transplantation of maxillary canines. Am J Orthod Dentofac Orthop 1996;90:149-57.

19. Isaacson RJ, Strauss RA, Bridges-Poquis A, Deluso AR, Lindaver SJ. Moving ankylosed central incisor using orthodontics, surgery and distraction osteogenesis. Angle Orthodontist 2001;71:411-8. 